\title{
Os dispositivos e o cuidado de si: a invenção do presente
}

Danichi Hausen Mizoguchi. Universidade Federal Fluminense.

\begin{abstract}
Resumo
O presente artigo debruça-se sobre os conceitos foucaultianos de dispositivos e de cuidado de si. A condução do trabalho desenvolve os caminhos que levaram Foucault a tal movimentação teórica, enxergando nessa modulação importantes implicações éticas e políticas no decurso teórico do autor, mas também - e sobremaneira - como arma cotidiana para os enfrentamentos das cada vez mais minuciosas batalhas contemporâneas. Desviada do contexto explícito no qual emerge a público - nos dois últimos volumes da História da sexualidade - e posto sob uma visada mais ampla - tal qual aparece nos cursos do Collège de France e em algumas entrevistas -, a aposta é que o conceito do cuidado de si possa ainda legar inquietações aos pesquisadores do presente.
\end{abstract}

Palavras-chave: ética, política, cuidado.

\begin{abstract}
Devices and self care: the invention of the present. This article focuses on the concepts Foucault devices and self care. The conduct of the work develops the paths that led Foucault to this theoretical movement, seeing in this modulation important ethical and political implications in the theoretical course of the author but also - and greatly - as everyday weapon for fighting the increasingly detailed contemporary battles. Diverted from the explicit context in which emerges to the public - in the last two volumes of the History of sexuality - and put under a larger view - as it appears in the Collège de France courses and some interviews - the bet is that the concept of care of itself can also leave worries the researchers of the present.
\end{abstract}

Keywords: ethics, politics, care.

\section{Resumen}

Dispositivos y autocuidado: la invención del presente. Este artículo se centra en los dispositivos de los conceptos de Foucault y autocuidado. La realización de la obra se desarrolla los caminos que llevaron Foucault a este movimiento teórico, viendo en esta modulación importantes implicaciones éticas y políticas en el curso teórico del autor, sino también - y en gran medida - arma como todos los días para combatir las batallas contemporáneas cada vez más detalladas. Desviado del contexto explícito en el que surge al público - en los dos últimos volúmenes de la Historia de la sexualidad - y puesto bajo una visión más grande tal como aparece en los cursos del Collège de France y algunas entrevistas - la apuesta es que el concepto de atención de sí mismo también puede mantener-se en las preocupaciones de los investigadores del presente.

Palabras clave: ética, política, cuidado. 
No intervalo de aproximadamente oito anos entre a publicação do primeiro e do segundo e terceiro volumes de A História da sexualidade, Michel Foucault (1976/1988, 1984, 1984/1985), debruçado, dentre outras coisas, sobre determinados aspectos da filosofia grega, descobre e matura noções importantes para uma bifurcação fundamental em suas pesquisas - e, dentre tais noções, a de o cuidado de si. Tal noção, porém, não é exclusivamente direcionada à problemática da sexualidade. Antes do lançamento de seus dois últimos livros, Foucault já havia trabalhado o conceito de cuidado de si sob uma visada mais ampla em alguns de seus cursos no Collège de France - ensejando com isso possíveis afrontas à supremacia forçosa dos jogos de poder.

Acerca de tal supremacia, há uma estranha concordância entre Pier Paolo Pasolini e Michel Foucault: ambos declaram, em momentos distintos, a atualidade de um mundo perigoso. O cineasta e poeta - ou, como preferia, o escritor - italiano, ao encerrar a última entrevista que deu em vida, poucas horas antes de ser assassinado entrevista na qual ensejou enunciar o rotundo fracasso da modulação capitalística, cravando um mundo em que os seres humanos se tornaram estranhas máquinas colidindo umas com as outras - sugeriu ao jornalista que desse a ela o título de "Estamos todos em perigo". O filósofo - ou, como preferia, o pirotécnico - francês, por outro lado, disse, também em uma entrevista, que "nem tudo é ruim, mas tudo é perigoso, o que não significa exatamente o mesmo que ruim. Se tudo é perigoso, então temos sempre algo a fazer" (Foucault, 1995, p. 256). O que tanto Pasolini quanto Foucault anunciam são os perigos do fascismo - ou, por outra, os perigos do microfascismo.

Porém, se é perigoso, este mesmo mundo está também sempre em vias de se inventar, e o cuidado de si parece fornecer importantes ferramentas ético-políticas a fim de que uma ontologia crítica do presente possa consistir. Assim, a intenção do presente artigo é emparelhar o conceito de cuidado de si às urgências do presente - urgências de um mundo tenso e perigoso, mas sempre em vias de ser destruído e inventado. Metodologicamente, não se trata de uma genealogia - no máximo uma mini-genealogia - do conceito de cuidado na obra de Foucault, mas de um estudo teórico o qual quer recolher, explicitar e circular as ferramentas - múltiplas, potentes, não limitadas a esta ou aquela luta - de afronta a um mundo onde se espraia com veemência o fascismo do saber e do poder, da norma, do governo das existências. Com a intenção de que tal ferramenta conceitual se descole de uma curiosidade de almanaque e se faça junto às lutas concretas, cotidianas e corporais da atualidade, a pergunta que impulsiona a escrita, portanto, é: qual a pertinência do cuidado de si junto às modulações perigosas do presente?

\section{Um Conceito}

Tornou-se famosa a passagem de Gilles Deleuze no velório de Michel Foucault. Misturado à pequena multidão silenciosa e em sincera comoção diante de um desaparecimento tido como prematuro (Dosse, 2010), o filósofo pôs-se sobre um caixote alocado em um canto do pátio e enunciou algumas palavras plagiadas vigorosamente de um texto escrito pelo amigo recém-falecido:

Quanto ao motivo que me impulsionou foi muito simples. Para alguns, espero, esse motivo poderá ser suficiente por ele mesmo. É a curiosidade - em todo caso, a única espécie de curiosidade que vale a pena ser praticada com um pouco de obstinação: não aquela que procura assimilar o que convém conhecer, mas a que permite separar-se de si mesmo. De que valeria a obstinação do saber se ele assegurasse apenas a aquisição dos conhecimentos e não, de certa maneira, e tanto quanto possível, o descaminho daquele que conhece? Existem momentos na vida em que a questão de saber se se pode pensar diferentemente do que se pensa, e perceber diferentemente do que se vê, é indispensável para continuar a olhar ou a refletir. Talvez me digam que esses jogos consigo mesmo têm que permanecer nos bastidores; e que no máximo eles fazem parte desses trabalhos de preparação que desaparecem por si sós a partir do momento em que produzem seus efeitos. Mas o que é filosofar hoje em dia - quero dizer, a atividade filosófica - senão o trabalho crítico do pensamento sobre o próprio pensamento? Se não consistir em tentar saber de que maneira e até onde seria possível pensar diferentemente em vez de legitimar o que já se sabe? Existe sempre algo de irrisório no discurso filosófico quando ele quer, do exterior, fazer a lei para os outros, dizer-Ihes onde está a sua verdade e de que maneira encontrá-la, ou quando pretende demonstrar-se por positividade ingênua; mas é seu direito explorar o que pode ser mudado, no seu próprio pensamento, através do exercício de um saber que lhe é estranho. O 'ensaio' - que é necessário entender como experiência modificadora de si no jogo da verdade, e não como apropriação simplificadora de outrem para fins de comunicação - é o corpo vivo da 
filosofia, se, pelo menos, ela for ainda hoje o que era outrora, ou seja, uma 'ascese', uma luta política, um exercício de si, no pensamento.Os estudos que seguem, assim como outros que anteriormente empreendi, são estudos de 'história' pelos campos que tratam e pelas referências que assumem; mas não são trabalhos de 'historiador'. O que não quer dizer que eles resumam ou sintetizem o trabalho feito por outros; eles são - se quisermos encará-los do ponto de vista de sua 'pragmática' - o protocolo de um exercício que foi longo, hesitante, e que frequentemente precisou se retomar e se corrigir. Um exercício filosófico: sua articulação foi a de saber em que medida o trabalho de pensar sua própria história pode liberar o pensamento daquilo que ele pensa silenciosamente, e permitir-lhe pensar diferentemente (pp. 13-14).

Um espólio se anunciava naquela passagem: a curiosidade que desencaminhava a pensar e perceber diferentemente. Os pensadores haviam sido muito próximos em idos tempos: travaram por anos a fio uma amizade filosófica, operando múltiplas sínteses disjuntivas ao longo de suas vidas. Ambos haviam se deslumbrado com os acontecimentos parisienses de maio de 1968, militado juntos em um grupo de informação sobre as prisões, de modos distantes e próximos forjaram filosofias do acontecimento, se entenderam e se desentenderam inúmeras vezes e, por fim, se afastaram. Na costura tensa e alegre desta relação é que Deleuze (1986/2005) dirigira a Foucault o questionamento póstumo: "o que aconteceu durante o silêncio bastante longo que se seguiu a Vontade de Saber?" (p. 101). A pergunta não era desprovida de sentido: referia-se ao hiato de oito anos entre o primeiro e o segundo volumes da História da sexualidade - a qual havia sido planejada e prometida por Foucault como obra de seis tomos encadeados e que fora abrupta e inesperadamente pausada.

A hipótese de Deleuze (1986/2005) e de tantos outros era que, tão logo finalizou o primeiro volume da História da sexualidade, Foucault tenha se visto incomodamente preso a certo modo de urdir perguntas e respostas: "talvez Foucault tenha percebido um certo equívoco ligado a este livro: não estava ele preso nas relações de poder?" (p. 101). O próprio Foucault sugerira que a resposta pudesse ser afirmativa. Em "A vida dos homens infames", texto escrito em 1977, escrevera:

Sempre a mesma incapacidade de ultrapassar a linha, de passar para o outro lado, de escutar e fazer ouvir a linguagem que vem de outro lugar ou de baixo... sempre a mesma escolha, do lado do poder, do que ele diz ou do que ele faz dizer (p. 204).

Mas o próprio Foucault (1977/2012) dissera, respondendo a si neste mesmo texto e ensaiando uma saída: o "ponto mais intenso das vidas, aquele em que se concentra sua energia, é bem ali onde elas se chocam com o poder, se debatem com ele, tentam utilizar suas forças ou escapar de suas armadilhas" (p. 204). Àquela altura, uma mudança - um ponto intenso de uma vida, o escape de uma armadilha - não seria algo inaudito em seu percurso intelectual.

Antes disso, Foucault houvera sido um arqueólogo do saber. Em livros como A história da loucura na Idade Clássica, O nascimento da clínica, As palavras e as coisas e A arqueologia do saber (Foucault, 1961/1978, 1963/1977, 1966/1999, 1969/2008) - todos editados na década de 1960 - interessaram-lhe sobremaneira as escavações de uma lógica enunciativa e um princípio de coesão dos saberes os quais possibilitavam e induziam sua existência em tal ou qual modo específico. Extraindo a historicidade daquilo que se queria o universal dos universais, colocava em suspenso todas as ditas ciências humanas e sua malfadada promessa de verdade absoluta fora do tempo. Mas era ele próprio que, percebendo equívocos metodológicos em sua própria pesquisa como era possível analisar o próprio arquivo e o que o permitia dizer aquilo que dizia eram perguntas que o punham frequentemente em saia justa -, fazia-se engendrado em um desvio já na próxima esquina.

Na década de 1970, Foucault operara a virada problemática, metodológica e conceitual em direção ao que chamara de genealogia. Não mais tanto o saber, mas já o poder - ou, precisamente, a efetivação da relação entre o saber e o poder - como foco de questionamento e de luta. Eram, por exemplo, produções como Vigiar e punir (Foucault, 1975/1987) - escrito após o movimento de criação e dissolução do Grupo de Investigação sobre as Prisões - pondo às claras o jogo das estranhas liberdades humanitárias da chamada sociedade disciplinar. O que se apresentava ali era o modo como, de instituição fechada em instituição fechada, formavam-se os dóceis corpos aptos a azeitar a máquina do capitalismo.

$\mathrm{Na}$ esteira de alguns cursos por ele ministrados, tornando mais minucioso tal maquinário, surgiu o primeiro volume da História da sexualidade (Foucault, 1976/1988). Colocando em suspenso a hipótese repressiva, o livro aludia a um jogo social no qual as manifestações sobre o sexo, menos do que barradas e mais do que autorizadas, eram convocadas como estatuto de verdade - e, portanto, 
vinculadas às chamadas relações de saber-poder. Em 1976, ano de confecção da obra, a sexualidade lhe interessava tomada como referencial privilegiado do movimento ocidental moderno de normalização biopolítica que se operava justamente em tal convocatória: quando se fala de sexo e de sexualidade, é sempre um dispositivo de poder sobre a vida que está em questão. Mas afinal, o que estava se chamando de dispositivo?

As duas primeiras dimensões de um dispositivo, ou aquelas que Foucault descobre e destaca em primeiro lugar, são as curvas de visibilidade e as curvas de enunciação - as curvas do saber, enfim. A visibilidade, neste maquinário, é sempre uma operação particular, pois não remete a uma luz geral e uniforme que viria iluminar objetos existentes desde sempre e que se esgueiraram à sombra por milênios, esperando ansiosamente a hora de serem descobertos. Ao contrário, a visibilidade é feita de linhas de luz que formam figuras variáveis inseparáveis deste ou daquele modo de iluminação: cria-se a luz dos objetos no exato instante em que cria os próprios objetos. Cada dispositivo, portanto, tem seu regime singular de luz, sua direção de fotografia - a maneira pela qual a luz cai distribuindo o visível e o invisível, o breu e o clarão, fazendo nascer ou desaparecer um objeto que jamais existiria sem ela. Considere-se o mesmo em relação às curvas de enunciação, nas quais se encontra tão somente aquilo que historicamente é possível ser dito - a linguagem tomada como potência e como limite.

Concretiza-se, sob esta dupla acepção, a brecha para a dimensão do poder - ou, como já se disse, a dimensão de um diferencial de forças que se estabelece em determinado maquinário. É assim, pois, que um dispositivo qualquer se compõe: com o saber e com o poder - ou com a luz e com a força. Caso seja possível dizer que, em um mundo repleto de forças, o poder é a concretização de um diferencial entre estas mesmas forças, o dispositivo - em uma primeira leitura - é aquilo que visa a efetivar ou manter o diferencial: ou seja, uma máquina que se presta a afetar de maneira particular as forças, formalizando determinado estado histórico. Assim, é sob a efetivação de um diferencial de forças que se dá a efetuação particular de grandes e pequenas funções sociais: modos de segurança, modos de saúde, modos de produção de riquezas, modos de delimitação de espaços, modos de desejo, modos de lazer (Razac, 2008). Trata-se, pois, em um sentido amplo, de considerar o dispositivo como uma máquina produtora de gestos, de condutas, de discursos: uma máquina produtora de modos de existência.
O pensador italiano Giorgio Agamben (citado por Castro, 2012) localizou na obra de Foucault um termo tomado dos escritos de Jean Hyppolite sobre Hegel e que pode ser considerado um antecedente ao surgimento do conceito de dispositivo: a positividade - entendida, longe de juízos de valor, como aquilo que faz as coisas existirem, dando a elas, portanto, um caráter positivo e não natural. Assim, sob esta passagem terminológica, Agamben pode fortalecer a noção de dispositivo, fazendo-a coincidente a todo e qualquer mecanismo apto a governar a vida, tendo como função justamente a captura dos viventes e a produção de modos de existência específicos: dispositivo, doravante, é tudo aquilo que faz com que a vida biológica - o simples fato da vida, ou o que os gregos chamavam zoé - passe a uma vida política - uma vida qualificada, ou o que os gregos chamavam bíos. O dispositivo é, pois, uma meada, um conjunto de múltiplas linhas no qual as coisas - os objetos visíveis, as enunciações formuláveis, as forças em exercício, os sujeitos numa determinada posição - funcionam como vetores ou tensores, afetando uns aos outros e sendo afetados uns pelos outros a fim de constituírem estilos de existência. O que se anuncia é um mundo radicalmente governável e governado: um mundo onde as relações saber-poder engendram sem cessar a subjetividade - um mundo tenso e perigoso porque repleto de dispositivos cotidianos que fazem da vida administrada a regra geral, exercendo o fascismo microfísico o qual se arvora o direito de enunciar e forçar este ou aquele modo de existência como normal e desejável.

Depois de cravar esta definição, Foucault descobre outra dimensão no jogo deste mesmo dispositivo: as linhas de subjetivação. Mais que todas as outras, a inserção conceitual desta terceira dimensão abre-se ao remanejamento do mapa dos dispositivos, encontrando para eles uma nova orientação possível na qual eles não mais se fecham sobre as linhas de força e sobre os regimes de luz e de enunciados intransponíveis os quais supostamente lhes imporiam contornos definitivos. Foucault descobre que os dispositivos que analisa não podem ser circunscritos por uma linha que os envolve sem que outros vetores passem acima, ao lado ou abaixo, aptos a estremecerem o diferencial de forças vigente sob os modos de iluminação, de enunciação e de força estabelecidos.

Tal invenção escapa às linhas precedentes: escapa, enfim, às urgências diretivas e diretas do saber e do poder. De tal modo, as três grandes instâncias que Foucault distingue sucessivamente em seu processo 
teórico-prático de análise - saber, poder e si - não possuem contornos definitivos: são, antes, cadeias variáveis relacionadas (Deleuze, 1986/2005). Isto porque em um dispositivo há linhas de sedimentação dos saberes e dos poderes, mas há também linhas que fraturam o modo de existência que se quer instaurado e replicado.

\section{Uma Ética}

A derradeira frase do primeiro volume da História da sexualidade chama a atenção: "Ironia deste dispositivo: é preciso acreditarmos que nisso está nossa 'liberação'" (Foucault, 1976/1988, p. 174). O ponto final daquele escrito era claro: demandava livrar-se das obsessões de decifração de verdade dos desejos, ao preço da manutenção da rede de poder e saber a qual pretende auxiliar na descoberta mesma de tal verdade justo lá onde se pensava que estaria a liberdade - posta, ali, entre as indispensáveis aspas da ironia: o dispositivo compunha-se então de saber e de poder. Em 1984, ano em que foram publicados os dois últimos tomos da História da sexualidade, a visada do autor já era claramente outra. Eis a primeira frase do segundo volume: "Esta série de pesquisas surge mais tarde do que eu previra e de uma forma inteiramente diferente" (Foucault, 1984, p. 9). Mas qual seria a diferença?

Em entrevista dada por Foucault na Universidade da Califórnia em abril de 1983, os pesquisadores estadunidenses Hubert Dreyfus e Paul Rabinow (1995) questionavam-no sobre a ausência de um segundo volume da História da sexualidade e sobre seu interesse geral acerca daquela temática. Foucault Ihes responde que, àquele momento, se via muito mais interessado nos problemas referentes às técnicas de si do que propriamente em sexo - simploriamente caracterizado como algo chato e posto como um assunto muito menos importante para os gregos do que outros como, por exemplo, a alimentação. Ao abordar as idas e vindas do próprio processo de trabalho empreendido na obra que estava em vias de se tornar tríplice, Foucault explica aos entrevistadores que logo após a publicação de $A$ vontade de saber havia escrito um segundo livro sobre a sexualidade, o qual rapidamente abandonou. Depois deste abandono, redigiu um tomo sobre as técnicas de si, do qual alijara o sexo - o qual também fora prematuramente abandonado. Por fim, escreveu um terceiro livro no qual tentava equilibrar essas vertentes: era o tardio e tão aguardado segundo volume da História da sexualidade, chamado de Uso dos Prazeres (Foucault, 1984).
Aproximadamente um ano após esta conversa com Dreyfus e Rabinow, em entrevista com François Ewald realizada para a Magazine Littéraire, Foucault (2006a) falava sobre os recém finalizados volumes: "Eis o que tentei reconstituir: a formação e o desenvolvimento de uma prática de si que tem como objetivo constituir a si mesmo como o artesão da beleza de sua própria vida" (p. 244). A questão era, portanto, radicalmente outra em relação ao volume publicado anos antes. O sexo e a sexualidade propriamente ditos apareciam agora quase como apêndices à ética que Foucault gostaria de pôr na ordem do dia: não mais os processos de assujeitamento, mas as modulações de subjetivação advindas da possibilidade de uma relação do sujeito consigo mesmo - tratava-se de inserir no jogo dos dispositivos uma força apta a afetar-se a si mesmo.

Foucault afirmava, de modo muito claro e enfático, que a ética do cuidado de si significava a produção de práticas de liberdade. A ética do cuidado de si podia fazer aparecer, finalmente explícito, um modo de confrontação direta ao poder político dos dispositivos de governo da existência - o saber e o poder. Tal viragem, todavia, não foi abrupta: a vereda que desembocou nos dois últimos volumes da História da sexualidade já vinha se insinuando antes.

Entre os anos de 1971 e 1984 - exceção feita a 1977 - Foucault ministrara no Collège de France cursos referentes à cátedra de História dos sistemas de pensamento. De acordo com as normas da instituição, a cada ano fazia-se necessário um estudo original - o que Ihe dava a possibilidade e o dever de conduzir o ensino com a vivacidade, o inacabamento e a inquietação de um pesquisador. Era ali, sob a urgência das demandas do presente e com "a feição de um laboratório vivo mais que de um balanço rígido" (Gros, 2006, p. 628), que Foucault podia tornar públicas as questões que fabricava.

Em 1980 e 1981, no curso nomeado "Subjetividade e verdade", a problemática aprofundava-se em torno da reflexão histórica sobre a vinculação entre os termos que nomeavam as preleções daquele ano. Na reflexão sobre a experiência greco-romana dos prazeres - os chamados aphrodísia -, indagava-se: como um sujeito foi historicamente estabelecido como objeto de conhecimento possível ou até mesmo indispensável? Tratava-se de recolocar o imperativo do conhece-te a ti mesmo, supervalorizado a partir de determinado momento histórico, na esfera mais ampla de outro imperativo: cuida-te a ti mesmo. Dava-se um passo importante, inaugural - mesmo que 
tímido - em direção às possibilidades de invenção de si: a suspensão genealógica da hegemonia do conhece-te a ti mesmo, da qual a posição monocórdia da ciência era devedora, posta agora apenas como uma das linhas de um cuidado e de uma criação de si por si.

Era, porém, no curso oferecido em 1981 e 1982, "A hermenêutica do sujeito", que encontrava-se o movimento crucial na virada problemática que o levou às bordas do cuidado de si. O objetivo central daquele curso era conseguir opor as práticas cristãs de confissão aos chamados exercícios espirituais antigos. Operava-se então uma dobra importantíssima no interior do tema da governamentalidade: ia-se do governo da vida ao governo de si. Era assim que Foucault, em um recuo temporal até então quase inédito em seus trabalhos, convidava a audiência a um retorno aos helenos. Mas, de fato, o que o fazia retornar à moral greco-romana? Será que ele abandonava o atordoamento do presente, no qual sempre estivera mergulhado, e se recolhia às curiosidades de gabinete?

O ponto nodal daquele curso era uma tentativa de revalorização da noção de cuidado de si mesmo epiméleia heautoû, em grego. Tratava-se de expressão poderosíssima no mundo heleno, a qual dava conta do ato de trabalhar ou estar preocupado consigo, e que naquele curso fora posta em relação de diferenciação à outra expressão não menos famosa: conhece-te a ti mesmo - gnôthi seauton, em grego. Historicamente mais próxima da científica e moderna noção de verdade e fundadora, talvez, das relações já problematizadas em cursos e livros antecedentes entre sujeito e verdade, era esta última a noção que deveria ser aprofundada se Foucault se dedicasse a seguir a mesma linha de pesquisa e ensino dos últimos questionamentos que havia elaborado. Todavia, optara por mergulhar na questão diagonal e historicamente marginal da epiméleia heautoû - ou do cuidado de si mesmo - apostando, talvez, que nela pudesse haver ferramentas as quais ajudassem a problematizar e a inventar o presente - ou, nos termos do próprio espólio capturado por Deleuze, pensar e perceber diferentemente.

Um dos pontos basais do curso indicava que o imperativo do conhece-te a ti mesmo não tinha na Antiguidade a acepção e a valorização presentemente conhecida. Um dos textos de Epicteto trabalhado naquele curso insinua que tal noção fora inscrito no centro da comunidade humana como algo que advinha dos preceitos indicados àqueles que consultavam o oráculo. Junto com dois outros imperativos célebres - nada em demasia e não faça promessas -, o conhece-te a ti mesmo indicava especificamente que o sujeito deveria averiguar em si o que é que carecia saber para só depois dirigir um questionamento ao delfo. Isto implica que o sujeito constitua-se face a si mesmo, e não como um alguém imperfeito, ignorante e que precisa, portanto, ser corrigido ou totalizado, formado e instruído, mas sim como indivíduo que sofre de certos males e que deve fazê-los cuidar, seja por si mesmo, ou por alguém que para isso tem competência. Cada um deve descobrir que está em estado de necessidade, e que lhe é necessário receber medicação e socorro (Foucault, 1984, pp. 62-63).

A função do cuidado de si era então mais abrangente e subordinava o conhecimento de si. Não era à toa que tal noção atravessara quase toda a cultura helenística e romana, tratando-se de "um verdadeiro fenômeno cultural de conjunto" (Foucault, 1981-1982/2006b, p. 13). Importava, àquele momento do curso, vincular e problematizar o âmbito do conhecimento, das condutas e do governo dos outros em uma reordenação valorativa das duas célebres expressões gregas, o cuidado e o conhecimento de si. Este fenômeno cultural aparecera na filosofia em torno de Sócrates, intimamente acoplado ao imperativo do conhece-te a ti mesmo. Porém, antes de ser uma recomendação filosófica maiêutica, era já uma sentença antiga da cultura grega de forma geral: quando retomada pela filosofia, já o era, portanto, a partir de uma consistente tradição. As aulas daquele curso versavam, assim, sobre uma noção importantíssima na história das práticas da subjetividade ocidentais. Mas, se era assim, cabia perguntar: por que a noção do cuidado de si havia sido colocada na penumbra a partir de determinado momento histórico? Foucault sugeria que parecia bastante "claro haver, para nós, alguma coisa um tanto perturbadora no princípio do cuidado de si" ( $p$. 16). Mais: "que a questão do sujeito ético é alguma coisa que não tem muito espaço no pensamento político contemporâneo" (p. 279). Mas que perturbação seria essa?

A tese apresentada no curso era que o sujeito da ação reta, muito presente na Antiguidade, foi historicamente substituído, no Ocidente moderno, pelo sujeito do conhecimento verdadeiro. O motivo principal do eclipse da prática do cuidado de si era aquilo que Foucault, ciente da má definição, chamou de momento cartesiano: não se tratava exatamente de uma invenção particular e pessoalizada de René Descartes, mas algo de que podia ser compreendido como uma atmosfera na qual, entre os séculos XVI e XVII, junto a outras mudanças marcantes para a história da humanidade, 
anunciava-se a plena desvinculação entre o conhecimento e o cuidado - notadamente em nome da qualificação do conhece-te a ti mesmo e desqualificação do cuida-te a ti a mesmo.

De acordo com tal leitura, a idade moderna da história da verdade começara no momento em que o que passa a permitir aceder ao verdadeiro é o próprio conhecimento - e tão somente ele. Era, nas palavras transcritas do curso, o momento no qual fora rompido definitivamente o vínculo "entre o acesso à verdade, tornado desenvolvimento autônomo do conhecimento, e a exigência de uma transformação do sujeito e do ser do sujeito por ele mesmo" (Foucault, 1981-1982/2006b, p. 35). Este marco de quebra - muito mais forte e amplo do que o dia em que, meditando em uma poltrona defronte à lareira de sua casa, Descartes enunciou o cogito ergo sum - deveria ser procurado prioritariamente junto à teologia - e não junto à ciência. Isto talvez porque a passagem entre o paganismo e o cristianismo operara a mudança da ordem da "reestruturação das formas da relação consigo e uma transformação das práticas e das técnicas sobre as quais essa relação se apoiava" (Foucault, 1984, p. 60).

Se é impossível "cuidar de si sem se conhecer" (Foucault, 2006c, p. 269), tal conhecimento, todavia, significa compreender as relações as quais constroem o sujeito - e, portanto, não "se dividir e fazer de si um objeto separado que seria preciso descrever e estudar, mas permanecer totalmente presente a si mesmo e estar completamente atento às suas próprias capacidades" (Gros, 2008, p. 131). Antes desta importante quebra histórica, porém, muita água rolou no leito do cuidado. Séculos antes dela, Sócrates já aparecia como aquele que tinha por função fazer com que os outros se ocupassem consigo. Foucault (1981-1982/2006b, p. 11) diz textualmente: "Sócrates é o homem do cuidado de si e assim permanecerá". O filósofo grego comparava-se ao tavão, inseto que pica os animais e os faz agitarem-se e correrem. O cuidado vinculava-se, nesta acepção de entomologia filosófica, a um princípio de permanente movimento e inquietude consigo no curso da existência humana. É por isso que, mais do que uma forma de atenção para consigo, tratava-se de ações que são exercidas de si para consigo, "pelas quais nos assumimos, nos modificamos, nos purificamos, nos transformamos e nos transfiguramos" (Foucault, 2006c, p. 14-15). Tratava-se, em outras palavras, de "uma atitude geral, um certo modo de encarar as coisas, de estar no mundo, de praticar ações, de ter relações com o outro" (p. 14), modelando uma atitude para consigo, para com os outros e para com o mundo.

Um dos pontos primeiros dos ensinamentos deste curso era a relação entre Alcibíades e Sócrates, notadamente quando aquele se dispõe a ouvir deste lições as quais o habilitassem a conquistar o comando político de Atenas. Dizia o filósofo ao jovem croqui de mandatário: o justo governo da cidade começa com o governo de si mesmo, e governar-se inevitavelmente implica em conhecer-se. Ocupar-se consigo e conhecerse a si mesmo apareciam plenamente vinculados na ordenação daquele que desejava e precisava, em um futuro não muito distante, comandar a muitos - um como condição do outro, já que não era legítimo dominar os outros sem que se tivesse, primeiro, domínio sobre si. Em Alcibíades, cuidar-se de si era conhecer-se a si - e conhecer-se a si significava conhecer o divino para reconhecer-se a si, e a partir de então distinguir bem e mal, verdadeiro e falso, a fim de conduzir-se e conduzir conforme se deve.

Na lição que Sócrates oferecia a Alcibíades, a noção de cuidado de si emergia exclusivamente entre o privilégio dos bem nascidos e a ação política de uma autoridade. Era, nestes termos, uma ideia e uma prática criadas exclusivamente no seio de um contexto elitista - o pequeno mundo dos jovens aristocratas os quais algum dia poderiam ou deveriam aos outros governar. Atingiam-se então tão somente os jovens ricos que desde a mocidade eram devorados pelo desejo de sobressair-se sobre os rivais: o cuidado de si era a prática que os preparava para passar a uma política ativa, autoritária e triunfante - já que sua fortuna, por si só, não lhes capacitaria a bem governar. Ao fim e ao cabo, o que aparecia em Alcebíades era a necessidade de ocupar-se consigo mesmo na medida em que se há de pôr em prática a arte de bem governar os outros: relação plenamente dissimétrica - e, mais do que isso, que sustentava e validava a dissimetria - fazendo diferentes da massa de pessoas absorvidas na vida de todos os dias aqueles que podiam pôr-se a cuidar de si.

No encontro entre Sócrates - o mestre - e Alcibíades - o jovem representante da elite - o eu era necessariamente a alma - e, especificamente, a alma entendida como o sujeito da ação:

não certa relação instrumental da alma com todo o resto ou com o corpo, mas, principalmente, a posição, de certo modo singular, transcendente, do sujeito em relação ao que o rodeia, aos objetos de que dispõe, como também aos outros com os 
quais se relaciona, ao seu próprio corpo e, enfim, a ele mesmo (Foucault, 1981-1982/2006b, p. 71).

Não a alma-substância, portanto, mas a almasujeito, da qual que se depreende que:

ocupar-se consigo mesmo será ocupar-se consigo mesmo enquanto se é 'sujeito de', em certas situações, tais como sujeito de ação instrumental, sujeito de relações com o outro, sujeito de comportamentos e de atitudes em geral, sujeito também da relação consigo mesmo. E sendo sujeito, este sujeito que se serve, que tem esta atitude, este tipo de relações, que se deve estar atento a si mesmo. Trata-se, pois, de ocupar-se consigo mesmo enquanto se é sujeito da khrêsis (com toda a polissemia da palavra: sujeito de ações, de comportamentos, de relações, de atitudes) (Foucault, 1981-1982/2006b, p. 71-72).

Assim, o ato de ocupar-se consigo depreendese, de forma bastante simples, do ato de conhecer a si mesmo, e é para conhecer-se a si mesmo que é preciso dobrar-se sobre si. Tratava-se de uma pista excelente, mas será que seriam exatamente estas - as que se atualizava nos abonados bem-nascidos que se queriam governantes - as relações as quais Foucault buscava a fim de finalmente ultrapassar a linha e estar fora daquilo que um dispositivo de poder diz ou faz dizer? Se não, que outro tipo de relação era esta que ele buscava ao propor um retorno aos antigos?

Desviando da cilada dos bem nascidos governantes gregos, Foucault chamava à problematização outro marco cronológico. Tratava-se dos dois primeiros séculos da nossa era, quando a principal inquietação de muitos filósofos era os modos de estabelecimento de uma relação adequada e plena de si para consigo. Tratava-se do momento o qual, imediatamente anterior à difusão imperial do cristianismo, fora qualificado naquele curso como a Idade de Ouro na história do cuidado de si - entendida tanto como prática quanto como noção e como instituição, e na qual desapareciam alguns preceitos básicos prementes naquilo que fora posto à época dos ensinamentos de Sócrates a Alcibíades.

Em primeiro lugar, desfazia-se o elitismo típico do momento anterior ao se propor que "ocupar-se consigo tornou-se um princípio geral e incondicional, um imperativo que se impõe a todos, durante todo o tempo e sem condições de status" (Foucault, 19811982/2006b, p. 103). Em segundo lugar, já não mais vigia a meta de preparação e requisito para um bom governo dos outros, já que "se se ocupa consigo agora, é por si mesmo e com finalidade em si mesmo" (p. 103). Por fim, o cuidado de si já não era mais vinculado à forma única do conhecimento de si - o qual mesmo que não tenha desaparecido, foi posto doravante misturado a uma série complexa de fatores.

Advinham, neste contexto, duas generalizações importantes: a extensão à própria vida cotidiana individual e a extensão a todos os indivíduos - quaisquer que fossem, futuros governantes ou não, mesmo que com algumas restrições políticas tipicamente gregas. Passou a haver, nesta época, uma relação de coextensividade entre o cuidado de si e a arte de viver - em grego, a tékhne toû bíou. A partir desta constatação, depreendia-se que doravante cuidar-se de si e dar-se à arte da vida e da existência já eram quase o mesmo.

O período helenístico poderia ser entendido, então, como aquele no qual se deu uma forte intensificação da relação consigo, experienciada doravante como uma criação de si. Não obstante, as problematizações referentes à epimeléia passavam a remeter a formas de atividades e de exercícios os quais Foucault, cheio de dedos em função do desgaste decorrido na longa tradição religiosa da palavra, classificava como ascéticos: naquele momento histórico - a idade de ouro - o cuidado de si passava a transbordar largamente o conhecimento, concernindo de fato a toda uma amplitude de práticas de si. Definia-se o movimento pertinente a esta passagem como uma "transmutação do cuidado de si em uma prática autônoma, auto-finalizada e plural nas suas formas" (Foucault, 1981-1982/2006b, p. 106). Dizia ele que havia modulações morais as quais eram orientadas para as formas de subjetivação, e não para os códigos: são as chamadas éticas - ou, no termo que ele vinha usando naquele trecho do curso, as asceses.

Entretanto, a partir do século II - e, sobretudo, do século IV - dá-se o movimento histórico de conversão cristã - o qual é uma das mais poderosas tecnologias do eu que o Ocidente conheceu. Quando a religião fez premente a noção de salvação, tornou-se necessário voltar-se a si mesmo, eliminando da atenção tudo aquilo que rodeia e distrai o sujeito. Não à toa, se é verdade que do século XVII em diante a disciplina e a normatização dos corpos e indivíduos tornou-se um fato social e político fundamental típico da modernidade, necessário fazer notar que todo esse processo foi antecipado pelo poder pastoral, já nos séculos XV e XVI, numa prática confessional impingida aos fiéis pela Igreja Católica. Mais do que isso, era importante salientar que tal prática era oriunda, talvez, daquele importante período vigente entre os séculos II e IV em que o cuidado vinculava-se à 
verdade: o conhecimento acerca do que os indivíduos pensam e o controle sobre suas atividades apareciam como duas faces de uma mesma moeda.

Nos séculos I e II de nossa era, porém, chegara-se a um ponto em que a cultura de si alcança níveis e dimensões consideráveis. Para os antigos helenos a ascese tinha um sentido quase oposto ao engendrado pelo cristianismo: referia-se a uma série de relações de si para consigo a fim de criar a transfiguração de si. Era já a radical prática deste discurso, sua ativação na própria atividade do sujeito, tornando-o sujeito ativo de tais enunciados e transformando finalmente o conhecimento em êthos - ou, em outros termos, em um modo de vida.

Algumas pistas puderam ser apreendidas nesta genealogia do cuidado empreendida por Foucault em seu curso A hermenêutica do sujeito, o qual apresentava historicamente o cuidado de si em oposição à renúncia de si e ao conhecimento de si. Grosso modo, delimitaram-se três momentos: o momento socráticoplatônico, no qual era preciso cuidar de si para cuidar dos outros; o momento helenístico e romano, notadamente representado por cínicos e estoicos, quando o cuidado de si torna-se um fim em si mesmo; e o momento cristão, quando volta-se para a salvação, para a ascese como superação e abdicação de si. O cuidado de si constituía, portanto, no mundo greco-romano, o modo pelo qual a liberdade individual - ou a liberdade cívica, até certo ponto - pôde ser pensada como ética (Foucault, 2006c). Via-se então a emergência de um si ético - ou seja, transformável, modificável, construído a partir de regras de existência e conduta e através de exercícios, práticas e técnicas -, mais do que um sujeito generalizável, originário e ideal (Gros, 2008).

Se assim era, para um grego a liberdade encontra sua modulação na arte de si mesmo - devendo, portanto, viver de modo a ter consigo a melhor relação possível tanto quanto para um habitante do presente. Essas pistas, em nada silenciosas, evidentemente iriam consistir nos livros vindouros de Foucault. Se de fato era válida a leitura que apontava o capital contemporâneo como aquela modulação social a qual trabalha disseminando dispositivos no maquinário coletivo, tal noção era por demais valiosa. Neste jogo de forças, a liberdade que conviria instaurar e preservar era uma certa forma de relação do indivíduo para consigo - para além de tudo aquilo que os tais dispositivos o faziam tender a ser.

Enfim, o cuidado de si não tem por intenção apartar o sujeito daquilo que o cerca, mas ser um dispositivo de criação e transfiguração do mundo: "o sujeito, descoberto no cuidado, é totalmente o contrário de um sujeito isolado: é um cidadão do mundo. O cuidado de si é, pois, um princípio regulador da atividade, de nossa relação com o mundo e com os outros" (Foucault, 1981-1982/2006b, p. 652). Versa-se, evidentemente, acerca de práticas as quais não são nem individuais nem comunitárias, mas relacionais e transversais. Portanto, não seria prudente concluir que ao enunciar uma ética do cuidado de si, Foucault tenha se esquecido de problematizar a política. Ao contrário, esta torção é justamente promotora de uma articulação entre o si, a ética e a política, já que:

a relação consigo não desvincula o indivíduo de toda e qualquer forma de atividade na ordem da cidade, da família ou da amizade; instaura antes, como dizia Sêneca, um intervallum entre essas atividades que ele exerce e o que o constitui como sujeito destas atividades (Foucault, 1981-1982/2006b, p. 652).

Parece que Foucault via-se ultrapassando a linha, já além e aquém daquilo que o poder dizia ou fazia dizer. Era com a invenção e o empréstimo de um novo sorriso que ele escapava do lugar de onde por anos e anos Ihe espreitavam - e de onde, também, por anos e anos espreitara o mundo: sorriso o qual, tempos depois, ainda seria gatilho para que confrontos e criações vigessem em um mundo inacabado.

\section{A Atualidade}

Era imperativo considerar que a importante passagem foucaultiana era um fértil legado aos pesquisadores do presente: já não mais tanto os holofotes voltados aos jogos de poder modernos, mas a penumbra das ruínas de uma ética antiga a qual intentava promover o governo da própria vida da forma mais bela possível. Mas, valorizada a passagem, fazia-se necessário considerar - como, aliás, já considerara o próprio Foucault: os gregos não são uma solução para os sujeitos do século XXI. Na esteira inventiva da trajetória de interrogações de Foucault talvez fosse premente extrair outros termos a fim de se reinventar intempestivamente os desencontros entre a subjetividade e o poder.

A despeito do grande esgotamento físico em que se encontrava pouco antes de falecer, em um gesto discreto e derradeiro de amizade para com Deleuze, Foucault aceitara a proposta de uma entrevista feita pelo jovem filósofo André Scala - amigo de Deleuze. 
Publicada três dias após a morte de Foucault, a entrevista explode em uma curiosa assertiva. Logo após todo o esforço de pesquisa e escrita que se dera no retorno aos gregos e na publicação de seus dois últimos livros, a frase soava surpreendente: "Toda Antiguidade me parece ter sido um 'profundo erro'" (Foucault, 2006d, p. 254). Para espanto de muitos, a modulação helena surge na entrevista como uma cultura que não era nem admirável nem exemplar -e sequer muito brilhante. Mesmo que os entrevistadores não tenham desenvolvido a pertinência da afirmativa, fundamental nos estertores de uma vida biológica que se acabava e de um pensamento que ajudaria a construir o presente quase trinta anos depois, o legado grego e foucaultiano livrava-se do peso de um modelo e se tornava ainda mais apto a problematizar as apostas do presente. Livrar-se do peso modelar, todavia, não significa que no contato com esta ou com aquela filosofia não se retivesse algo com o qual pudesse produzir esforços de construção da atualidade: o que urgia enfatizar era que tal coisa porvir seria simultaneamente enredada em uma trama antiga de inspirações e inevitavelmente nova. Mas, de fato, que inspirações são essas que eram legados nas últimas problematizações erigidas por Foucault?

A afirmação é de Deleuze (1986/2005): "eis o que fizeram os gregos: dobraram a força, sem que ela deixasse de ser força. Eles a relacionaram consigo mesma" (p. 108). Disto decorre um poder da força de se afetar a si mesma: um afeto de si por si. O que Foucault findara por encontrar era "uma dimensão da subjetividade que deriva do poder e do saber, mas que não depende deles" (p. 109). De onde se conclui que talvez algo fundamental a ser aprendido e tomado como inspiração contemporânea nos estudos derradeiros de Foucault é a possibilidade feita luta de se pensar o sujeito como autor de si próprio, constituindo-se eticamente em dobras do poder as quais permitem que se crie o mundo.

Se o que Foucault sempre fizera em suas pesquisas fora colocar o sujeito no domínio histórico das práticas e dos processos, a estranha e inspiradora novidade era que doravante o sujeito poderia emergir no tenso cruzamento entre técnicas de dominação e técnicas de si. Era assim que uma existência tornava-se a dobra dos processos de subjetivação sobre os processos de sujeição, em duplicações concomitantemente históricas e singulares. Se o cuidado de si é uma prática necessariamente social, é assim que, mergulhada nas demandas do presente, a ética que Foucault retoma dos gregos permite reivindicar aquela que, por variados motivos, é uma das grandes questões contemporâneas. Urgia replicar uma famosa questão, tornando-a tão nova quanto fosse possível: a que preço e a que condições seria possível constituir uma estética e uma ética de si sob os auspícios daquele território o qual se fazia repleto de dispositivos?

Se o mundo do presente é pleno de forças organizadas em dispositivos, a agonística do enfrentamento levantava o pressuposto de que os campos de luta estão sempre abertos, já que constituídos pelas tais forças em lutas estratégicas sem descanso. Trata-se, talvez, de um trabalho a ser realizado sobre si mesmo o qual se daria a criar as condições de existência com o outro, urdindo territórios micropolíticos coletivos de criação e de experimentação. Assim, o grande interesse de Foucault em verificar como essa prática "se integra num tecido social e constitui um motor de ação política" (Gros, 2008, p. 131) virava a aposta sem programa e a herança aberta e valiosa de seus últimos cursos, entrevistas e escritos.

Se a noção do cuidado de si era profícua, o motivo para tal não residia na segurança de esconder-se debaixo da saia das últimas produções de Foucault, mas nos pontos de toque entre as problemáticas que foram as dele e as que parecem ser urgentes no presente: é essa, aliás, a maravilha de um aprendizado que não cobra replicação. De fato, a ética repensada por Foucault como um discurso e uma prática de resistência (Nealon, 2008) o é sempre como inventiva intempestiva do presente. $\mathrm{O}$ que ele mostra claramente é que o cuidado de si introduz entre o sujeito e o mundo uma certa distância a qual é precisamente constitutiva da ação: abertura de espaço em um mundo repleto de fechamentos.

Fazendo-se contemporânea, urge fazer coro a Deleuze (1986/2005) e perguntar: será que "as mutações do capitalismo não encontram um 'adversário' inesperado na lenta emergência de um novo Si como foco de resistência?" (p. 123). A aposta era de que sempre haverá uma relação consigo a qual resiste aos ordenamentos de forças dos códigos e dos poderes - a qual força passagem a pensar e a perceber diferentemente. Porém, se na analítica de Foucault as relações de poder somente se afirmam efetuando-se, a relação consigo, que as verga, também só pode se estabelecer efetuando-se. Doravante entre o si e si mesmo talvez se pudesse abrir a cuidadosa distância de uma obra de arte a ser criada: a vida e o mundo. 


\section{Referências}

Castro, E. (2012). Introdução a Giorgio Agamben: uma arqueologia da potência. Belo Horizonte: Autêntica.

Deleuze, G. (2005). Foucault. São Paulo: Brasiliense. (Obra original publicada em 1986)

Dosse, F. (2010). Gilles Deleuze e Felix Guattari: uma biografia cruzada. Porto Alegre: Artmed.

Dreyfus, H., \& Rabinow, P. (1995). Michel Foucault: uma trajetória filosófica: (para além do estruturalismo e da hermenêutica). Rio de Janeiro: Forense Universitária.

Foucault, M. (1977). O nascimento da clínica (R. Machado, Trad.). Rio de Janeiro: Forense Universitária. (Obra original publicada em 1963)

Foucault, M. (1978). História da loucura na idade clássica (C. Netto, Trad.). São Paulo: Perspectiva. (Obra original publicada em 1961)

Foucault, M. (1984). História da sexualidade: o uso dos prazeres (Vol. 2). Rio de Janeiro: Graal.

Foucault, M. (1985). História da sexualidade: o cuidado de si (Vol. 3). Rio de Janeiro: Graal. (Obra original publicada em 1984)

Foucault, M. (1987). Vigiar e punir: nascimento da prisão (R. Ramalhete, Trad.). Petrópolis, RJ: Vozes. (Obra original publicada em 1975)

Foucault, M. (1988). História da sexualidade: a vontade de saber (Vol. 1). Rio de Janeiro: Graal. (Obra original publicada em 1976).

Foucault, M. (1995). Sobre a genealogia da ética: uma revisão do trabalho. In P. Rabinow \& H. Dreyfus (Orgs.), Uma trajetória filosófica: para além do estruturalismo e da hermenêutica (pp. 253-278). Rio de Janeiro: Forense Universitária.

Foucault, M. (1999). As palavras e as coisas: uma arqueologia das ciências humanas ( $8^{a}$ ed., S. T. Muchail, Trad.). São Paulo: Martins Fontes. (Obra original publicada em 1966)
Foucault, M. (2006a). O cuidado com a verdade. In M. B. Motta (Org.), Ética, sexualidade e política (Vol. 5, pp. 240-251, Coleção Ditos \& Escritos). Rio de Janeiro: Forense Universitária.

Foucault, M. (2006b). A hermenêutica do sujeito. São Paulo: Martins Fontes. (Obra original publicada em 1981-1982)

Foucault, M. (2006c). A ética do cuidado de si como prática da liberdade. In M. B. Motta (Org.), Ética, sexualidade e política (Vol. 5, pp. 264-287, Coleção Ditos \& Escritos). Rio de Janeiro: Forense Universitária.

Foucault, M. (2006d). O retorno da moral. In M. B. Motta (Org.), Ética, sexualidade e política (Vol. 5, pp. 252-263, Coleção Ditos \& Escritos). Rio de Janeiro: Forense Universitária.

Foucault, M. (2008). A arqueologia do saber ( $7^{a}$ ed., L. F. B. Neves, Trad.). Rio de Janeiro, Forense Universitária. (Obra original publicada em 1969)

Foucault, M. (2012). A vida dos homens infames. In: M. B. Motta (Org.), Estratégia poder-saber (Vol. 4, pp. 199-217, Coleção Ditos \& Escritos). Rio de Janeiro: Forense Universitária. (obra original publicada em 1977)

Gros, F. (Org.). (2006). Situação do curso. In F. Ewald \& A. Fontana (Orgs.), A hermenêutica do sujeito/Michel Foucault (pp. 127-138). São Paulo: Martins Fontes.

Gros, F. (2008). O cuidado de si em Michel Foucault. In M. Rago \& A Veiga-Neto (Orgs.), Figuras de Foucault (pp. 127-138). Belo Horizonte: Autêntica.

Nealon, J. (2008). Foucault beyond Foucault: power and its intensifications since 1984. Stanford, CA: Stanford University Press.

Razac, O. (2008). Avec Foucault après Foucault: disséquer la société de controle. Paris: L'Harmattan.

Danichi Hausen Mizoguchi, Doutor em Psicologia pela Universidade Federal Fluminense, é Professor do Departamento de Psicologia e do Programa de Pós-Graduação em Psicologia pela Universidade

Federal Fluminense: Rua João Afonso, no 49/504. Rio de Janeiro/RN, CEP:22.261-040. E-mail: danichihm@hotmail.com 